\title{
Analisis Strategi Relationship Marketing Pada BMT NU Pragaan Kabupaten Sumenep
}

\author{
Achmad Tarmidzi Anas ${ }^{1^{*}}$, Ismail $^{2}$ \\ 1) Institut Agama Islam Al-Khairat Pamekasan \\ 2) Institut Agama Islam Muhammadiyah Bima \\ *Corresponding Author: achmadtarmidzianas5@gmail.com
}

\begin{abstract}
ABSTRAK - Penelitian ini bertujuan untuk (1) menganalisis strategi relationship marketing pada BMT NU Pragaan Kabupaten Sumenep, (2) menganalisis implikasi relationship marketing pada BMT NU Pragaan Sumenep. Penelitian dilakukan menggunakan pendekatan kualitatif, dengan jenis peneltian studi kasus. Teknik pengumpulan data yang dilakukan dengan menggunakan metode observasi, wawancara dan dokumentasi. Sedangkan pengecekan keabsahan data menggunakan trianggulasi teknik. Hasil penelitian menunjukkan bahwa strategi yang dibangun adalah: Pertama, menyediakan berbagai jenis produk secara kompleks. Kedua, menjalin silaturahmi dengan mengadakan pertemuan rutin di daerah-daerah prioraitas yang memiliki prospek besar dalam menjalankan pemasaran. Ketiga, mempererat hubungan serta menjalin kerjasama dengan beberapa instansi atau lembaga tertentu pada beberapa kegiatan tertentu untuk tetap menjaga hubungan dengan nasabah. Keempat, memberikan pelayanan jemput bola untuk memudahkan nasabah dalam melakukan transaksi. Kelima, menghadiri beberapa kegiatan lembaga pendidikan untuk menjaga hubungan kekeluargaan serta menjaga ikatan emosional dengan nasabah. Adapun implikasinya, mampu menarik minat nasabah untuk melakukan transaksi serta meningkatkan loyalitas nasabah lama terhadap BMT NU karena terbentuknya kepercayaan serta rasa nyaman dengan hubungan yang dibangun. Sehingga strategi relationship yang dibangun oleh BMT NU mampu meningkatkan citra positif terhadap masayarakat.
\end{abstract}

Kata Kunci - Strategi; Relationship marketing

\section{PENDAHULUAN}

Pada era saat ini, kegiatan masyarakat yang bernilai ekonomis tidak dapat terlepas dari strategi pemasaran, hal ini dikarenakan kebutuhan yang sangat urgen akan strategi pemsaran yang baik guna untuk dapat bersaing dalam ketatnya persaingan dalam memperebutkan pelanggan pada era pasar bebas saat ini. Sehingga segala bentuk kegiatan ekonomi yang menawarkan produk penjualan atau jasa berusha keras untuk mencapai target pemasarannya.

Secara global, pemasaran berguna untuk menciptakan permintaan terhadap suatu produk barang atau jasa melalui berbagai strategi relationship marketing guna mencapai berbagaimacam pemenuhan kebutuhan konsumen. Oleh karena itu, perusahaan melakukan berbagai macam identifikasi untuk dpaat mengetahui serta mengelopokkan beberapa kebutuhan prioritas yang diperlukan oleh kondisi pasar saat itu untuk memperebutkan konsumen. 
Fokus pemasaran kini telah berubah, dari pemasaran berbasis transaksi yang hanya menjadikan pelanggan sebagatas konsumen, bergeser menjadi pemasaran berbasis relation, sehingga perusahaan menjadikan pelanggan sebagai rekanan dan mitra dalam jangka waktu yang panjang. Sehingga perusahaan membuat komitmen jangka panjang kepada pelanggan dengan memperbaiki kualitas layanan dan selalu menciptakan inovasi terbaru sesuai dengan kebutuhan dan perkembangan.

Pemasaran berupaya untuk mengidentifikasi dan memenuhi kebutuhan manusia dan sosial. ${ }^{1}$ Maka dari itu, dlam melaksanakan pemasaran, perusahaan dituntut untuk memiliki keahlian untuk membuat pelanggan merasa nyaman dan puas dari transaksi yang dilakukan. Hal ini akan menjadi sangat urgen disaat kondisi persaingan pada sector ekonomi semakin ketat.

Relationship marketing meciptakan, menjaga serta meningkatkan hubungan yang kuat dengan pelanggan yang ada, daripada mencari pelanggan yang baru. Relationship marketing bertujuan untuk membangun hubungan yang baik serta berkesinambungan dlam jangka waktu panjang. ${ }^{2}$ Penggunaan relationship sendiri bisa digunakan dalam ruang lingkup bisnis atau dalam ruang lingkup yang lebih luas. Sehingga untuk mendapat bertahan dlam kerasnya persaingan dalam dunia usaha, maka perusahaan dituntut untuk menjaga hubungan yang baik untuk meningkatkan loyalitas pelanggannya.

Strategi pemasaran relationship marketing juga dapat diaplikasikan pada sebuah lembaga keuangan bank dan non bank dalam menawarkal produk yang tersedia kepada nasabah. Sedangkan paradigma yang perlu dibangun untuk bersaing pada banyanknya lembaga keuangan bank non bank yang muncul saat ini adalah membangun hubungan sebaik mungkin serta selama mungkin dengan nasabah untuk menjaga harmonisasi yang baik untuk menjaga nasabah agar tidak berpaling kepada lembaga yang lain.

Keharomnisan antara lembaga keuangan bank dan non bank dengan nasabah menjadi penting karena antara lembaga keuangan dengan nasabah memiliki hubungan timbal balik dan saling membutuhkan. Nasabah membutuhkan lembaga keuangan untuk mempermudah setiap transaksi yang akan dilakukan, sedangkan lembaga keuangan membutuhkan nasabah untuk menjalakan bisnisnya dan menjual produknya sesuai dengan yang telah direncanakan.

Penelitian ini difokuskan kepada lembaga keuangan non bank, yaitu BMT NU Pragaan Kab, Sumenep. Berawal dari BMT NU Pusat yang terletak di

9.

${ }^{1}$ Philip Kotler, Kevine Lane Keller, Manajemen Pemasaran, Jilid 1, (Jakarta: Erlangga, 2009), h.

${ }^{2}$ Philip Kotler, Prinsip-Prinsip Pemasaran, Jilid 2, (Jakarta: Erlangga, 2001), h. 304. 
kabupaten sumenep, BMT NU menjadi lembaga keuangan yang berkembang pesat di Jawa Timur dan memiliki banyak cabang baik di Madura ataupun di wilayah jawa timur lainnya, serta menarik banyak minat masyarkat untuk melakukan transaksi di berbagai cabang di kota-kota tertentu. Beberapa strategi yang lumrah dilakukan adalah mengemas beberapa produk semenarik mungkin untuk menarik minat nasabah dalam melakukan transaksi didalamnya, serta banyak langkah-langkah lain yang dilakukan untuk membangun relationship marketing dengan nasabah.

Berdasarkan fenomena diatas, penelitian ini bertujuan untuk mengetahui bagaimana stratergi relationship marketing pada BMT NU Pragaan Kabupaten Sumenep, serta bagaimana implikasinya terhadap perkembangan usaha BMT NU Pragaan Kabupaten Sumenep.

\section{METODE PENELITIAN}

Metode penelitian ini menggunakan pendekatan kualitatif, pendekatan kualitatif merupakan suatu prosedur penelitian yang menghasilkan data deskriptif yang berupa kata-kata secara tertulis maupun secara lisan berdasarkan objek yang dapat diamati. ${ }^{3}$ Sedangkan jenis penelitian ini adalah studi kasus, merupakan suatu penelitian yang menempatkan objek yang diteliti sebagai kasus.

Dalam penelitian ini, peneliti bertindak sebagai suatu instrument yang mengharuskan untuk turun secara langsug ke lapangan yang menjadi objek penelitian dalam penelitian yang dengan jenis kualitatif. Sedangkan sumber datanya adalah data primer dan sekunder. Tehnik pengumpulan data yang digunakan dalam penelitian ini adalah observasi, wawancara dan dokumentasi.

\section{TINAJUAN PUSTAKA \\ Relationship Marketing}

Relationship marketing adalah menciptakan, menjaga serta meningkatkan hubungan yang kuat antara perusahaan dengan pelanggan. Strategi pemasaran yang berbasis relationship marketing memliki orientasi jangka panjang. Tujuannya adalah untuk memberikan suatu nilai kepada pelanggan dalam jangka panjang. Sedangkan ukuran keberhasilannya adalah kepuasan pelanggan pada jangka panjang.

Setiap perusahaan atau lembaga keuangan diharuskan untuk membangung hubungan yang baik dengan pelanggan sebagai salah satu strategi pemasaran dalam kondisi usaha yang sangat kompetitif. Strategi membangun

\footnotetext{
${ }^{3}$ Lexy J. Moleong, Metodologi Penelitian Kualitatif. (Bandung: Remaja Rosdakarya. 2010), h. 4.
} 
hubungan mulai banyak diterapkan oleh banyak perusahaan karena diangga efektif untuk mengurangi tingkat kehilangan pelanggan, mengurangi biaya promosi untuk menarik minat pelanggan baru, serta dapat menambah tingkat pinghasilan dalam jangka panjang. 4 saat ini banyak perusahaan yang menggunakan starategi relationship marketing untuk menjaga para pelanggan untuk tetap loyal terhadap perusahaan dengan mempelajari dan memenuhi segela bentuk kebutuhan pelanggan sebaik mungkin.

Strategi pemasaran berbasis relationship marketing, terdiri dari beberapa aktivitas, seperti aktivitas menarik pelanggan baru, menjaga pelanggan yang sudah ada, serta meningkatkan hubungan menjadi lebih baik kepada pelanggan baru maupun kepada pelanggan yang sudah lama. Apabila hubungan tersebut dapat berkembang dan terjalin dengan baik, maka secara tidak langsung pelanggan yang sudah ada, akan membantu perusahaan untuk malakukan promosi dan menarik pelanggan baru secara tidak langsung.

Strategi tersebut akan memberikan kenyamanan kepada pelanggan untuk tetap beraktivitas dan menjalin hubungan dengan perusahaan, selama perusahaan tetap menjaga hubungan yang baik dengan pelanggan, sehingga pelanggan merasa nyaman dengan setiap aktivitas serta transaksi yang terjadi. Namun demikian, apabila segala bentuk kebutuhan pelanggan terpenuhi serta tercapainya kepuasan pelanggan dengan baik, makan akan semakin kecil kemungkinan untuk terjadinya perpindahan pelanggan kepada perusahaan lain.

Setiap pelanggan yang telah loyal, cenderung untuk melakukan transaksi yang berulang-ulang dengan intensitas yang lebih sering daripada sebelumnya, sehingga akan menjadi target pemasaran yang starategis bagi perusahaan dalam menjual berbagai macam produk yang telah tersedia.

Pada umumnya, pelanggan akan berfikir bahwa yang mereka harapkan adalah keyakinan terhadap apa yang akan didapatkan ketika melakukan transaksi dengan perusahaan tertentu. ${ }^{5}$ Berdasarkan hal tersebut, perusahaan perlu untuk memiliki suatu persepsi yang sama dengan pelanggan untuk memperoleh hasil yang melebihi harapan pelanggan, bahkan paling tidak, sama atau memenuhi standard harapan serta kebutuhan pelanggan.

\section{Manfaat Relationship Marketing}

Perusahaan yang menggunakan strategi pemasaran relationship akan menguntungkan kedua belah pihak, bukan hanya perusahaan yang akan menikmati setiap keuntungan dalam penggunaan strategi ini, melainkan pelanggan juga akan memperoleh benefit dalam hubungan tersebut.

\footnotetext{
${ }^{4}$ Alfansi, Financial Service Mariketing, (Jakarta: Salemba Empat, 2010), h. 125.

${ }^{5}$ Fajar Laksana, Manajemen Pemasaran, (Yogyakarta: Graha Ilmu, 2008), h. 9.
} 
Beberapa manfaat yang dapat dinikmati dalam konteks pemasaran berbasis relationship marketing, adalah sebagai berikut:

\section{Benefit Untuk Perusahaan}

Terdapat banyak manfaat yang dapat dinikmati oleh perusahaan apabila mereka mampu untuk menerapkan strategi relationship marketing dengan efektif. Beberapa manfaat yang dikasud antara lain: 6

1. Peningkatan pembelian

Benefit bagi perusahaan yang pertama adalah kedcenderungan pelanggan untuk menggunakan produk secara berulanga dan jumlah yang lebih banyak setelah pelanggan merasakan kepuasan dengan perusahaan tertentu. Sehingga hal ini dapat memicu timbulnya relation yang lebih baik dengan perusahaan.

2. Perusahaan membutuhkan waktu untuk memperoleh keuntungan

Waktu untuk memperoleh keuntungan dari pelanggan ini berlaku untuk setiap pelanggan baru, karena setiap pelanggan baru cenderung akan lebih sedikit dan lebih berhati-hati dalam melakukan transaksi dengan perususahaan. Sehingga perusahan diperlukan kesabaran ekstra dan strategi yang lebih matang untuk membuat pelanggan baru tersebut merasa nyaman dan terpenuhi kebutuhannya. Apabila hubungan relationship marketing yang dibangun berjalan dengan baik, maka pelanggan akan menjadi pelanggan yang loyal terhadap perusahaan.

3. Penurunan biaya

Manfaat selanjutnya yang dapat dirasakan oleh perusahaan adalah dapat menekan biaya yang harus dikeluarkan untuk iklan dan mempromosikan produk perusahaan. Sehingga mempertahankan pelanggan yang sudah ada akan jauh mengurangi serta meringankan biaya dan pengeluaran financial perusahaan.

4. Peluang membina hubungan antar generasi

Salah satu hal yang perlu diperhatikan dalam relationship marketing adalah menjaga hubungan yang baik dengan salah satu anggota keluarga pelanggan, karena hal tersebut secara tidak langsung dapat memberikan promosi gratis kepada anggota keluarga yang lain sehingga akan mempengaruhi anggota keluarga yang lain pada masa yang akan datang.

5. Dampak positif word of mouth

Kebiasaan yang lumrah dilakukan oleh pelanggan adalah menggali beberapa informasi yang berkaitan dengan perusahaan kepada keluarga atau kerabat dekat untuk menentukan perusahaan yang pas untuk dijadikan

${ }^{6}$ Alfansi, Financial Service h. 132 .

J-ESA (Jurnal Ekonomi Syariah) 
sebagai tujuan transaksi. Sehingga pelanggan yang loyal biasanya akan merekomendasiksan kepada pelanggan baru. Sehingga rekomendasi dari pelanggan lama yang telah loyal terhadap perusahaan ini cenderung lebih efektif untuk meyakinkan pelanggan baru dalam menarik minat untuk bertransaksi, daripada promosi yang yang dilakukan langsung oleh perusahaan baik melalui promosi atau strategi periklanan lainnya.

6. Employe retention

Dampak tidak langsung yang dapat dinikmati perusahaan dari strategi relationship marketing ini adalah perusahaan dapat memperhatikan kinerja karyawan dan pada waktu yang bersamaan perusahaan dapat menjaga costumer base mereka. Adapun manfaat utama dari relationship marketing yang kuat serta fokus terhadap pelanggan dan tingkat kepuasannya adalah akan tercipta tingkat loyalitas pelanggan yang tinggi. ${ }^{7}$ Suatu kegiatan ekonomi dan bisnis dengan fokus pelanggan yang kuat, akan menjadikan kedudukan kedudukan terbaik bagi perusahaan untuk menjalankan dan mengembangkan bisnis yang dijalankan.

\section{Benefit Untuk Pelanggan}

Beberapa manfaat yang dapat dinikmati oleh pelanggan dalam setiap hubungan yang terjalin dlam jangka waktu panjang dengan perusahaan melalui strategi relationship marketing adalah :

1. Confidence benefit

Confidence benefit merupakan suatu perasaan yakin terhadap terhadap perusahaan, munculnya perasaan nyaman kepada pelanggan karena perusahaan mengetahui dan mengerti apa yang dibutuhkan oleh pelanggan, serta berkurangnya rasa cemas yang dirasakan oleh pelanggan apabila merekea melakukan transaksi yang yang cukup besar dengan pelanggan. Sehinggan rasa aman dan nyaman yang diberikan oleh perusahaan akan mengikat hati nasabah untuk tidak beralih kepada perusahaan lain.

2. Social benefit

Social benefit meupakan suatu strategi relationship dalam menambahkan manfaat sosial yang bisa dirasakan oleh pelanggan, serta berusaha memberikan pelayanan yang sidatnya lebih pribadi kepada pelanggan untuk meningkatkan ikatan social.

Manfaat social benefit ini akan muncul apabila terjalin hubungan yang cukup lama antara pelanggan dan perusahaan. Sehingga apabila manfaat ini sudah terbentuk, akan sangat sulit kemungkinan pelanggan untuk berlaih kepada perusahaan lain yang menyediakan produk atau jasa

\footnotetext{
${ }^{7}$ Sofjan Assauri, Strategic Marketing, (Jakarta: Rajawali Press, 2012), h. 7.
} 
yang sejenis, meskipun terdapat program serta penawaran yang lebih baik dari perusahaan lain.

3. Special treatment benefit

Special treatment benefit atau manfaat perlakuan khusus bisa didapatkan serta dirasakan oleh pelanggan apabila relationship yang dibangun oleh perusahaan dan pelanggan sudah berlangsung cukup lama, manfaat perlakuan khusus ini dapat berupa banyak hal yang bisa ditawarkan oleh perusahaan kepada pelanggan, seperti penawaran jasa khusus yang lebih menarik, adanya perlakuan yang lebih istimewa daripada pelangaan yang lain, atau dapat berupa potongan harga, serta perlakuan khusus lainnya sesuai dengan kebijakan perusahaan. Beberapa tindakan yang akan dilakukan pelanggan ketika sudah merasa nyaman dan puas terhadap apa yang diterima dari perusahaan adalah: 8

a. Tidak berpindah kepada perusahaan lain;

b. Mengulang kembali pembelian produknya;

c. Membeli kembali produk yang berbeda pada perusahaan yang sama;

d. Memberikan promosi gratis dari mulut ke mulut.

Beberapa alasan lain yang dapat menjadi alasan pekanggan untuk tetap loyal terhadap suatu perusahaan meski mendapatkan penawaran yang lebih baik oleh perusahaan lain adalah sebagai berikut: ${ }^{9}$

a. Pelanggan merasa nyaman dengan relation yang ada;

b. Pelanggan tahu apa yang diharapkan;

c. Pelanggan memiliki hubungan yang baik dengan karyawan perusahaan;

d. Pelanggan merasa yakin akan dilayani dengan baik jika memiliki permintaan khusus.

\section{Proses Pengembangan Relationship Marketing}

Terdapat beberapa tahapan yang perlu dilalui oleh perusahaan untuk menjadikan pelanggan menjadi loyal. Tahapan tersebut adalah sebagai berikut:

1. Prospect. Merupakan calon konsumen yang telah dipetakan oleh perusahaan untuk dijadikan sebagai sasaran pemebeli potensial dari setiap produk atau jasa yang ditawarkan.

2. Customer. Merupakan pelanggan yang baru pertama kali melakukan transaksi atau baru beberapa kali melakukan transaksi dengan perusahaan.

3. Client. Merupakan tahapan selanjutnya, yaitu pelanggan sudah mulai nyaman dalam melakukan transaksi untuk perusahaan dan menjadi pelanggan reguler bagi perusahaan.

\footnotetext{
${ }^{8}$ Kasmir, Pemasaran Bank, (Jakarta: Kencana, 2008), h. 162.

${ }^{9}$ Alfansi, Financial Service ............. h. 130.
} 
4. Supporter. Pada tahap ini, pelanggan sudah mulai mendukung segala bentuk aktivitas perusahaan serta mendukung berbagai macam produk perusahaan kepada orang lain.

5. Advocate. Tahap ini menjadi tahap puncak dari proses hubungan pelanggan dengan perusahaan, yakni pelanggan secara aktif ikut membela perusahaan dalam setiap keadaan.

Diperlukan bagi perusahaan unutk dapat memilah dan memilih calon pelanggan yang prospek atau termasuk dalam kategori calon pembeli yang potensial, setelah calon pelanggan tersebut menggunakan atau membeli salah satu jasa maupun produk dari suatu perusahaan, maka pelanggan tersebut sudah termasuk dalam kategori konsumen.

Tantangan selanjutnya bagi perusahaan adalah untuk membuat pelanggan melakukan transaksi secara berulang secara reguler dan mejadikan mereka sebagi pelanggan yang loyal terhadap perusahaaan. Tahapan selajutnya adalah, perushaan perlu untuk mengetahui perilaku pelanggan, sehingga perushaan memiliki tantangan untuk membuat pelanggan memiliki sikap yang positif terhadap perusahaan serta produk dan jasa yang ditawarkan, sehingga pelanggan akan mendukung perusahaan dalam setiap kegiatan yang dilakukan serta membela perusahaan dalam keadaan tertentu, sehingga dapat membereikan berita positif tentang perusahaan serta produknya kepada orang lain. ${ }^{10}$

\section{Elemen Pemasaran Berbasis Relationship}

Dasar strategi relationship marketing dalam jangka waktu yang panjang bergantung kepada kualitas layanaan yang diberikan oleh perusahaan serta kualitas karyawan secara personal, apabila terjadi kegalan dalam memenuhi beberapa kebutuhan dasar pelanggan, hal tersebut akan membuat pelanggan merasa tidak puas dengan hubungan yang terjalin.

Apabila komunikasi pemasaran dilakukan secara tepat serta mampu memenuhi kebutuhan dan keinginan dari pelanggan, maka pemahaman akan kebutuhan serta keinginan pelanggan menjadi sangat penting. ${ }^{11} \mathrm{Hal}$ ini menjadi satu faktor penting dalam menciptakan proses hubungan relationship yang baik.

Upaya dalam mempertahankan pelanggan untuk tetap menjadi bagian dari konsumen yang loyal terhadap perusahaan merupakan bagian penting dalam pengembangan strategi relationship marketing. Proses pengembangan hubungan perusahaan dengan pelanggan bergantung kepada dua elemen, yaitu

\footnotetext{
${ }^{10}$ Alfansi, Financial Service h. 130.

${ }^{11}$ Tatik Suryani, Dkk, Manajemen Koperasi, (Yogyakarta: Graha Ilmu, 2008), h. 27.
} 
1. Janji (promise);

2. Kepercayaan (trsut).

\section{HASIL PENELITIAN}

Baitul Mal Wat Tamwil (BMT NU) lahir berangkat dari sebuah keprihatinan atas kondisi kesejahteraan ekonomi masyarakat Sumenep pada umumnya yang tidak ada peningkatan secara signifikan. Salah satu gagasan yang yang mendsari berdirinya BMT NU sebagai lembaga keuangan mikro syariah yang bergerak pada usaha simpan pinjam bagi anggotanya adalah berdasarkan keprihatinan semakin merajalelanya parakter rentenir yang terjadi dimasyarakat.

BMT NU Pragaan merupakan sebuah lembaga keuangan non bank yang terletak di Desa Pakamban Kecamatan Pragaan Kabupaten Sumenep. Lembaga tersebut merupakan salah satu cabang yang memiliki prestasi yang menjanjikan dengan penghargaan sebagaikantor cabang dengan kinerja terbaik.

Upaya yang dilakukan oleh BMT NU Pragaan dalam membangun hubungan yang baik dengan nasabah untuk tetap mempertahankan eksistensi lembaga keuangan ditengah ketatnya persaingan pada bidang ekonomi sector lembaga keuangan bank dan non bank adalah dengan beberapa strategi, yakni: Pertama, menyediakan berbagai jenis produk secara kompleks. Strategi ini dilakukan oleh BMT NU untuk mengakomodir segala bentuk kebutuhan nasabah, sehingga dengan tersedianya pilihan produk yang lebih variatif, akan lebih memudahkan nasabah serta memberikan banyak pilihan sesuai dengan produk yang dibutuhkan oleh nasabah. Variasi produk yang cukup banyak menjadi salah satu cara yang dilakukan untuk memahami segala bentuk kebutuhan nasabah serta menyediakannya untuk meningkatkan kepuasan nasabah dalam bertransaksi di BMT NU. Beberapa produk yang ditawarkan oleh BMT NU Pragaan Kabupaten Sumenep adalah sebagai berikut:

\section{Produk Tabungan}

\section{SIAGA (Simpanan Anggota)}

SIAGA disedikan bagi yang berminat untuk menjadi anggota BMT NU dengan bagi hasil 70\% dari SHU dengan menggunakan akad Musyarakah.

\section{SIDIK Fathonah (Simpanan Pendidikan Fathonah)}

Simpanan untuk siswa dan orang tua siswa yang ingin meraih cita-cita pendidikan secara sempurna dengan bagi hasil 45\% yang menguntungkan dengan menggunakan akad Mudharabah Muthlaqah serta dapat disetor kapan saja dan hanya dapat ditarik pada saat tahun ajaran baru.

\section{SAJADAH (Simpanan Berjangka Wadiaah Berhadiah)}

J-ESA (Jurnal Ekonomi Syariah) 
Simpanan dengan keuntungan yang dapat dinikmati di awal dengan memperoleh hadiah langsung tanpa diundi, menggunakan akad Wadi'ah Yadl Al-Dhammanah dan dapat ditarik pada waktu berdsarkan ketentuan yang berlaku.

\section{SIBERKAH (Simpanan Berjangka Mudharabah)}

Simpanan dengan keuntungan yang melimpah dengan bagi hasi $65 \%$ menggunakan akad Mudharabah Muthlaqah.

\section{SAHARA (Simpanan Haji dan Umrah)}

Simpanan yang dapat mempermudah anda menunaikan haji dan umrah dengan memperoleh keuntungan yang melimpah dengan bagi hasil $65 \%$ sebagai bekal tambahan haji dan umrah dengan menggunakan akad Mudharabah Muthlaqah.

\section{SABAR (Simpanan Lebaran)}

Simapanan yang dapat mempermudah untuk memenuhi kebutuhan lebaran dengan menggunakan akad Mudharabah Muthlaqah.

\section{TABAH (Tabungan Mudharabah)}

Simpanan yang dapat mempermudah pemenuhan kebutuhan sehari-hari karena setoran dan penarikan yang dapat dilakukan kapan saja dengan menggunakan akad mudharabah Muthlaqah.

\section{TARAWI (Tabungan Ukhrawi)}

Tabungan sekaligus beramal, karena bagi hasil tabungan akan disedekahkan kepada fakir miskin dan anak yatim piatu dengan menggunakan akad Mudharabah Muthlaqah.

\section{Produk Pembiayaan}

\section{Al-Qardul Hasan}

Merupakan pembiaayaan dengan jasa seikhlasnya tanpa bagi hasil dan margin.

1. Mudharabah dan Bai' Bitsamanil Ajil

Pembiayaan dengan pola jual beli barang. Harga pokok diketahui bersama dengan harga jual berdasarkan kesepakatan bersama. Selisih harga pokok dengan harga jual merupakan margin bagi BMT NU, dengan harga sama baik menggunakan angsuranan bulanan ataupun cash tempo.

2. Mudharabah dan Musyarakah

Pembiayaan seluruh modal kerja (Mudharabah) atau sebagian modal kerja (Musyarakah) dengan pola bagi hasil, bagi hasil dihitung berdasarkan keuntungan yang sebenarnya sesuai dengan kesepakatan.

3. Rahn/Gadai 
Pembiayaan dengan menyerahkan barang atau bukti kepemilikan barang sebagai tanggungan pinjaman dengan nilai minjaman maksimal $80 \%$.

\section{Produk Jasa}

Adapaun produk jasa yang ditawarkan oleh BMT NU Yaitu:

1. Transfer antar bank dalam negeri maupun luar negeri

2. Pendaftaran haji dan umrah

3. Pembayaran tagihan PLN, Telephone, Internet, Pulsa, Dll.

4. Pembayaran biaya pendidikan Perguruan Tinggi.

\section{Menyediakan layanan BMT NU Mobile}

Penyediaan layanan BMT NU Mobile ini diharapkan dapat mempermudah nsabah dalam melakukan transaksi dimanapun berada, nasabah tidak perlu mendatangi kantor BMT NU, dan cukup melakukan transaksi melalui android. Hal ini menjadi respon yang dilakukan oleh BMT NU terhadap persaingan lembaga keuangan bank dan non bank di era modern saat ini. Kedua, menjalin silaturrahmi dengan mengadakan pertemuan rutin di daerah-daerah prioraitas yang memiliki prospek besar dalam menjalankan pemasaran. Kegiatan ini dilakukan oleh BMT NU Pragaan dengan mengadakan pertemuan setiap bulan dengan para anggota serta nasabah di desa-desa tertentu yang menjadi basis nasabah BMT NU untuk tetap menjaga ikatan silaturrahmi serta mendengarkan beberapa keluhan dan masukan dari anggota dan nasabah. Kemudian BMT NU menindak lanjuti keluhan dan masukan tersebut dalam beberapa kebijakan yang dianggap perlu setelah pertemuan tersebut. Ketiga, mempererat hubungan serta menjalin kerjasama dengan beberapa instansi atau lembaga tertentu pada beberapa kegiatan tertentu untuk tetap menjaga hubungan dengan nasabah, seperti dengan mengadakan sistem kerja sama pengelolaan tabungan dengan sekolah, strategi ini dilakukan untuk memperluas relasi BMT dengan nasabah dengan menjadikan lembaga atau instansi tertentu sebagai narahubung. Keempat, memberikan pelayanan jemput bola untuk memudahkan nasabah dalam melakukan transaksi, karyawan BMT NU siap menjemput dan atau mengantarkan tabungan atau pembiayaan nasabah ke rumah, kantor, pasar atau tampat masing-masing, dengan hanya tinggal menghubungi nomor petugas yang telah disediakan. Strategi dikenal sebagai strategi jemput bola dengan tujuan untuk memberikan kemudahan kepada nasabah dalam melakukan transaksi serta memberikan kepuasan dan kenyamanan kepada nasabah, karena dengan adanya pelayanan ini, nasabah bisa menghemat waktu dan tenaga serta baiaya dalam melakukan transaksi. Kelima, menghadiri beberapa kegiatan lembaga pendidikan untuk menjaga hubungan kekeluargaan serta menjaga ikatan emosional dengan nasabah. Dalam

J-ESA (Jurnal Ekonomi Syariah) 
starategi ini, BMT NU turut serta mendukung beberpa kegiatan lembaga pendidikan, dengan mengahdiri kegiatan tertentu seperti haflatul imtihan, pengajian akbar dan beberapa kegiatan besar lainnya. Selain itu, BMT NU juga memberikan kontribusi kepada kegiatan lembaga tersebut berupa memberikan hadiah bagia siswa tauladan, serta memberikan sumbangan finansial kepada lembaga pendidikan serta lembaga keagamaan tertentu. Dengan menggunakan strategi ini, BMT NU dapat menarik minat masyarakat untuk melakukan transaksi serta dapat meningkatkat loyalitas nasabah untuk tetap membangun retionship yang baik dengan BMT NU.

Adapun implikasi dari relationship marketing yang dibangun oleh BMT NU dengan Nasabah melalui beberapa tindakan dalam membangun hubungan secara langsung seperti penyediaan produk yang sangat variatif untuk menapung berbagai kebutuahn masyarakan teransaksi tertentu, memberikan pelayanan jemput bola, mengadakan pertemuan rutin di dareah-daerah basis nasabah yang besar. Atau melalui retionship yang dilakukan untukmembangun hubungan dengan nasabah secara tidak langsung seperti menngunakan media kerjasama dengan lembaga atau instansi tertentu, atau dengan memberikan santunan atau sumbangan terhdap kegiatan lembaga pendidikan dan lembaga keagaamaan tertentu. Sehingga mampu menarik minat nasabah untuk melakukan transaksi serta meningkatkan loyalitas nasabah lama terhadap BMT NU karena terbentuknya kepercayaan serta rasa nyaman dengan hubungan yang dibangun. Sehingga strategi relationship yang dibangun oleh BMT NU mampu meningkatkan citra positif terhadap masayarakat.

\section{PEMBAHASAN}

\section{Strategi Relationship marketing BMT NU Pragaan Kabupaten Sumenep}

Relationship marketing mempersyaratkan semua elemen perusahaan untuk bekerja sama sebagai sebuah tim untuk melayani pelanggan. Kerja sama tersebut melibatkan terciptanya suatu hubungan pada banyak tingkatan ekonomis, teknis, serta legal. Sehingga dapat menghasilkan tingkat loyalitas pelanggan yang tinggi terhadap suatu perusahaan. ${ }^{12}$ Pelayanan terhadap nasabah menjadi salah satu strategi yang paling penting dalam membangun hubungan dengan pelanggan.

Pelanggan cenderung akan selalu melakukan transaksi dengan perusahaan yang telah lama dikenalnya, daripada menaruh harapan terhadap perusahaan baru yang belum dikenalnya. Sehingga apabila perusahaan konsisten untuk memperhatikan segala bentuk kebutuhan dan keinginan

${ }^{12}$ Philip Kotler, Prinsip-Prinsip ,h. 304. 
pelanggan, maka pelanggan cenderung akan tetap belangganan dengan perusahaan dan terus menjaga relationshipnya. ${ }^{13}$ pemenuhan kebutuhan pelanggan dapat diaplikasikan dengan menyedian beberapa produk yang sesuai dengan kebutuhan pelanggan. Hal ini selaras dengan hasil temuan peneliti, bahwa BMT NU menyediakan berbagai jenis produk secara kompleks. Strategi ini dilakukan oleh BMT NU untuk mengakomodir segala bentuk kebutuhan nasabah, sehingga dengan tersedianya pilihan produk yang lebih variatif, akan lebih memudahkan nasabah serta memberikan banyak pilihan sesuai dengan produk yang dibutuhkan oleh nasabah. Variasi produk yang cukup banyak menjadi salah satu cara yang dilakukan untuk memahami segala bentuk kebutuhan nasabah serta menyediakannya untuk meningkatkan kepuasan nasabah dalam bertransaksi di BMT NU.

Kebutuhan dasar menjadi ukuran dasar perusahaan dalam strategi relationship marketing, karena untuk meciptakan rasa nyaman, aman dan memberikan kepuasan pelanggan, maka harus terpenuhi beberapa kebutuhan dasar pelanggan, sebagai berikut: ${ }^{14}$

1. Dimengerti;

2. Merasa disambut dan nyaman;

3. Merasa penting dan dihormati

4. Terpenuhi kebutuhannya.

Sedangkan keberhasilan relationship marketing bagi perusahaan ditentukan oleh empat faktor, yakni:

1. Kepercayaan;

2. Kualitas layanan;

3. Peran karyawan;

4. Kemampuan perusahaan menangani keluhan pelanggan. ${ }^{15}$

Kualitas yang dimakasud pada poin (b) di atas selaras dengan strategi yang telah diterapkan oleh BMT NU Pragaan. Yakni dengan memberikan pelayanan jemput bola untuk memudahkan nasabah dalam melakukan transaksi, karyawan BMT NU siap menjemput dan atau mengantarkan tabungan atau pembiayaan nasabah ke rumah, kantor, pasar atau tampat masing-masing, dengan hanya tinggal menghubungi nomor petugas yang telah disediakan. Strategi dikenal sebagai strategi jemput bola dengan tujuan untuk memberikan kemudahan kepada nasabah dalam melakukan transaksi serta memberikan kepuasan dan kenyamanan kepada nasabah, karena dengan adanya pelayanan

${ }^{13}$ Buchari Alma, Manajemen Pemasaran dan Pemasaran Jasa, (Bandung: Alfabeta, 2011), 274.

14 Marilyn Manning, Patricia Haddock, manajemen Kantor: Panduan Produktivitas dan Efektifitas, (Jakarta Barat: PT Indeks, 2010), h. 96.

${ }^{15}$ Alfansi, Financial Service............, h. 138. 
ini, nasabah bisa menghemat waktu dan tenaga serta baiaya dalam melakukan transaksi.

Kemampuan menangani keluhan pelanggan sebagai mana dimaksud pada poin $(\mathrm{d})$ diatas, selarang dengan temuan yang dilakukan peneliti yakni dengan menjalin silaturrahmi dengan mengadakan pertemuan rutin di daerahdaerah prioraitas yang memiliki prospek besar dalam menjalankan pemasaran. Kegiatan ini dilakukan oleh BMT NU Pragaan dengan mengadakan pertemuan setiap bulan dengan para anggota serta nasabah di desa-desa tertentu yang menjadi basis nasabah BMT NU untuk tetap menjaga ikatan silaturrahmi serta mendengarkan beberapa keluhan dan masukan dari anggota dan nasabah. Kemudian BMT NU menindak lanjuti keluhan dan masukan tersebut dalam beberapa kebijakan yang dianggap perlu setelah pertemuan tersebut.

Setiap perusahaan atau lembaga keuangan diharuskan untuk membangung hubungan yang baik dengan pelanggan sebagai salah satu strategi pemasaran dalam kondisi usaha yang sangat kompetitif. Strategi membangun hubungan mulai banyak diterapkan oleh banyak perusahaan karena diangga efektif untuk mengurangi tingkat kehilangan pelanggan, mengurangi biaya promosi untuk menarik minat pelanggan baru, serta dapat menambah tingkat pinghasilan dalam jangka panjang. 16 saat ini banyak perusahaan yang menggunakan starategi relationship marketing untuk menjaga para pelanggan untuk tetap loyal terhadap perusahaan dengan mempelajari dan memenuhi segela bentuk kebutuhan pelanggan sebaik mungkin.

Hal tersebut selaras dengan hasil penelitian ini, bahwa Mempererat hubungan serta menjalin kerjasama dengan beberapa instansi atau lembaga tertentu pada beberapa kegiatan tertentu untuk tetap menjaga hubungan dengan nasabah, seperti dengan mengadakan sistem kerja sama pengelolaan tabungan dengan sekolah, strategi ini dilakukan untuk memperluas relasi BMT dengan nasabah dengan menjadikan lembaga atau instansi tertentu sebagai narahubung.

Menghadiri beberapa kegiatan lembaga pendidikan untuk menjaga hubungan kekeluargaan serta menjaga ikatan emosional dengan nasabah. Dalam starategi ini, BMT NU turut serta mendukung beberpa kegiatan lembaga pendidikan, dengan mengahdiri kegiatan tertentu seperti haflatul imtihan, pengajian akbar dan beberapa kegiatan besar lainnya. Selain itu, BMT NU juga memberikan kontribusi kepada kegiatan lembaga tersebut berupa memberikan hadiah bagia siswa tauladan, serta memberikan sumbangan finansial kepada lembaga pendidikan serta lembaga keagamaan tertentu. Dengan menggunakan strategi ini, BMT NU dapat menarik minat masyarakat untuk melakukan

${ }^{16}$ Ibid, h. 125 
transaksi serta dapat meningkatkat loyalitas nasabah untuk tetap membangun retionship yang baik dengan BMT NU.

\section{Implikasi Strategi Relationship Marketing BMT NU Pragaan Kabupaten Sumenep}

Pelanggan akan tetap loyal kepada suatu perusahaan apabila menerima nilai yang relative dengan nilai yang ditawarkan oleh perusahaan lain, pelanggan akan menggunakan perceived value untuk menilai keguanaan suatu produk berdasarkan persepsi yang akan diterima. ${ }^{17}$ Berdasarkan hal tersebut, pelanggan memiliki kemungkinan yang besar untuk tetap menjalin hubungan dengan perusahaan ketika menerima benefit yang sesuai dan kualitas yang sepadan dengan biaya yang telah dikeluarkan. Hal ini selaras dengan temuan peneliti, bahwa implikasi dari relationship marketing yang dibangun oleh BMT NU dengan Nasabah melalui beberapa tindakan dalam membangun hubungan secara langsung seperti penyediaan produk yang sangat variatif untuk menapung berbagai kebutuahn masyarakan teransaksi tertentu, memberikan pelayanan jemput bola, mengadakan pertemuan rutin di dareah-daerah basis nasabah yang besar. Atau melalui retionship yang dilakukan untukmembangun hubungan dengan nasabah secara tidak langsung seperti menngunakan media kerjasama dengan lembaga atau instansi tertentu, atau dengan memberikan santunan atau sumbangan terhdap kegiatan lembaga pendidikan dan lembaga keagaamaan tertentu. Sehingga mampu menarik minat nasabah untuk melakukan transaksi serta meningkatkan loyalitas nasabah lama terhadap BMT NU karena terbentuknya kepercayaan serta rasa nyaman dengan hubungan yang dibangun. Sehingga strategi relationship yang dibangun oleh BMT NU mampu meningkatkan citra positif terhadap masayarakat.

\section{KESIMPULAN}

Dalam membangun hubungan relationship marketing dengan nasabah, BMT NU menggunakan beberapa strategi agar untuk bisa tetap memperhankan nasabah labah dan menarik sabah baru ditengan ketatnya persaingan memperebutkan nasabah pada kondisi persaingan industry keuangan yang sangat ketat seperti saat ini.

Beberapa strategi relationship marketing yang dibangung oleh BMT NU Pragaan adalah sebagai berikut:

1. Menyediakan berbagai jenis produk secara kompleks.

${ }^{17}$ Buchari Alma, Manajemen Pemasaran... h. 274 . 
2. Menjalin silaturrahmi dengan mengadakan pertemuan rutin di daerahdaerah prioraitas yang memiliki prospek besar dalam menjalankan pemasaran.

3. Mempererat hubungan serta menjalin kerjasama dengan beberapa instansi atau lembaga tertentu pada beberapa kegiatan tertentu untuk tetap menjaga hubungan dengan nasabah.

4. Memberikan pelayanan jemput bola untuk memudahkan nasabah dalam melakukan transaksi.

5. Menghadiri beberapa kegiatan lembaga pendidikan untuk menjaga hubungan kekeluargaan serta menjaga ikatan emosional dengan nasabah.

Adapun implikasi dari relationship marketing yang dibangun oleh BMT NU dengan Nasabah melalui penyediaan produk yang sangat variatif untuk menapung berbagai kebutuahn masyarakan teransaksi tertentu, memberikan pelayanan jemput bola, mengadakan pertemuan rutin di dareah-daerah basis nasabah yang besar. Atau melalui retionship yang dilakukan untukmembangun hubungan dengan nasabah secara tidak langsung seperti menngunakan media kerjasama dengan lembaga atau instansi tertentu, atau dengan memberikan santunan atau sumbangan terhdap kegiatan lembaga pendidikan dan lembaga keagaamaan tertentu. Sehingga mampu menarik minat nasabah untuk melakukan transaksi serta meningkatkan loyalitas nasabah lama terhadap BMT NU karena terbentuknya kepercayaan serta rasa nyaman dengan hubungan yang dibangun. Sehingga strategi relationship yang dibangun oleh BMT NU mampu meningkatkan citra positif terhadap masayarakat. 


\section{DAFTAR PUSTAKA}

Alfansi, 2010, Financial Service Mariketing, Jakarta: Salemba Empat.

Anis Fuad, 2014, Panduan Praktis Penelitian Kualitatif. Yogyakarta: Graha Ilmu.

Buchari Alma, 2011, Manajemen Pemasaran dan Pemasaran Jasa, Bandung: Alfabeta.

Fajar Laksana, 2008, Manajemen Pemasaran, Yogyakarta: Graha Ilmu.

J. Vredenbregt. 1984, Metode dan Tehnik Penelitian Masyarakat. Jakarta: Gramedia.

Kasmir, 2008, Pemasaran Bank, Jakarta: Kencana.

Lexy J. Moleong, 2010, Metodologi Penelitian Kualitatif. Bandung: Remaja Rosdakarya.

M Aziz Firdausi. 2012, Metodologi Penelitian. Tangerang: jelajah Nusa.

Marilyn Manning, Patricia Haddock, 2010, manajemen Kantor: Panduan Produktivitas dan Efektifitas, Jakarta Barat: PT Indeks,

Maryaeni. 2012, Metodologi Penelitian Kebudayaan. Jakarta: PT Bumi Aksara.

Philip Kotler, Kevine Lane Keller, 2009, Manajemen Pemasaran, Jilid 1, Jakarta: Erlangga.

Philip Kotler, 2001, Prinsip-Prinsip Pemasaran, Jilid 2, Jakarta: Erlangga.

Sofjan Assauri, 2012, Strategic Marketing, Jakarta: Rajawali Press.

Tatik Suryani, Dkk, 2008, Manajemen Koperasi, Yogyakarta: Graha Ilmu. 